\title{
Relationship between CRM Strategy and Hotels' Performance with Reference to Madurai
}

\author{
S.Senthil kumar, J.Prabhu
}

\begin{abstract}
Customer Relationship Management is an ideology to manage company's interaction with existing and future customers. Today it is an inevitable for any business because of heavy competition and globalization. Every organization thrives to withstand in the competition for that they have to retain their customers as well as develop their products. Especially for the hotel industry it has to come up with distinctive ideas to show their uniqueness in the industry as well as with their current and potential customers. However there will be a limited study in the survey area about CRM. This observation strive to manifest how the impact of Customer Relationship Strategy with organizational performance.
\end{abstract}

Keywords: CRM, Madurai, Organizational Performance, CRM Strategy, Globalization.

\section{INTRODUCTION}

CRM in recent time begin to be the most debatable issue and a backbone in the business fields [1] [2]. It is imperative that CRM is basically founded on the conviction that building up an association with clients is the foundation for acquiring faithful who are substantially more gainful than non-steadfast ones [3]. In such manner, the effective usage of CRM technique will be of appreciative advantage to the association, receiving it, all things considered associations can receive the reward of expanding deals through better market division, tailor-made items and administrations, getting higher quality items, accessing data and worker fulfillment or more all client maintenance and dedication [4] [2] [5] [6]. Anyway in the ongoing investigations on the CRM generally centre around a few service industries, for example, banking [7], media transmission [4] [8], Healthcare [9], and contact focus [8]. Thus there is constrained research on CRM in the hospitality business [11] [12].

In addition, several researches mention the significance of making studies on CRM proportions in the hotel sector [7]. Hence this study mainly focus on significant relationship between CRM with hotel performance and customer retention
Revised Manuscript Received on December 20, 2019.

* Correspondence Author

S.Senthil kumar*, Department of Catering Science and Hotel Management, Kalasalingam Academy of Research \& Education, Krishnankoil, Tamilnadu, India.. Email:ssenthilkumar@klu.ac.in

J.Prabhu, Department of Catering Science and Hotel Management, Kalasalingam Academy of Research \& Education, Krishnankoil, Tamilnadu, India.. Email: prabhu.j@klu.ac.in

\section{LITERATURE REVIEW}

\section{A. CRM strategy and Performance}

A few experimental investigations have demonstrated that CRM acquires advantage terms of improved performance [9]. CRM can upgrade firm execution through improving consumer loyalty and gratification, reducing client obtaining costs and expanding benefit by clients [10]. Execution is improved since CRM includes the active procedure advancement of market insight for structure and keeping up a benefit amplifying arrangement of client relationship [9]. In spite of the fact that not all CRM technique execution realizes these ideal advantages [11], viable administration of client relationship using CRM Strategy is relied upon to have a positive association with performance.

In hospitality industry, Customer relationship management turns into a vital basic for quantitative and expanding visitor's support [12]. Along these lines the appropriation of CRM should upgrade the lodging execution through expanding consumer loyalty and faithfulness, declining client procurement costs and expanding gainfulness by clients who are happy to pay a premium for better administrations [10].

\section{B. Customer Related Performance Measures}

Hotels are urged to do some strategy to retain its potential guests and to withstand in the competitive industry. For these hotels, the utilization of the budgetary measures isn't just transient situated yet in addition insufficient to catch the client point of view of execution [13]. Client related execution measures are consequently expected to evaluate client connections and to separate clients who are deserving of the CRM endeavors' [14].

\section{HOTEL INDUSTRY AND CRM}

CRM carries advantages to the organization that creates a great deal of data about clients [15]. Moreover, Gronroos (2004) [16] mention that service organization for their inherent qualities of the creation and utilization are indistinguishable components important to manufacture association with clients. Effective execution of CRM hotels can get a great deal of data about the visitors, such information can be changed into helpful learning about them [17] [18] [19]. Along these lines it is clear that such aggressive points must be accomplished through usage of CRM, which will bring about building up productive connection among organization and their clients [20]. 
Obviously, CRM is broadly considered as a standout amongst the best approaches to encourage creating and extending the client's base that, thusly, will help with upgrading gainfulness and visitor unwaveringness [21] [22].

\section{METHODOLOGY}

A structured questionnaire was circulated to the star hotels of Madurai to know the CRM Strategy was following in the organization as well as how the CRM influences in customer performance and retention. Some questionnaire sections acquired predominantly from Brown and Gulyez [23] (2002). The responses chose the 5 point linear scale from 1 to 5 respectively strongly Disagree \& Strongly Agree and 1 to 5 respectively not at all used \& greatly used. The results were analysed based on the score given by the respondents.

\section{RESULTS}

The researchers circulated a total of 80 questionnaires to the employees of the star category hotels in Madurai for collecting the data. Out of which 80 Questionnaire only 60 response got from the respondent. The questionnaire was split into two sections. In $1^{\text {st }}$ section the questions are based on the CRM strategy following in the organization and in the $2^{\text {nd }}$ section the questions to measure the customer retention and satisfaction level.

\section{SECTION - I - CRM STRATEGY}

\section{A.Users Feedback to improve product and services}

The majority of the respondents agreed that they are collecting feedback from their stakeholders to the betterment of the product and services shown in Fig. 1. Around 45\% and $23 \%$ of the total respondents strongly agree and agree respectively. It shows that the most of the hotels in Madurai collecting feedback to withstand from their competitors and the respondents confirm that it will be very useful in their product and service improvement.

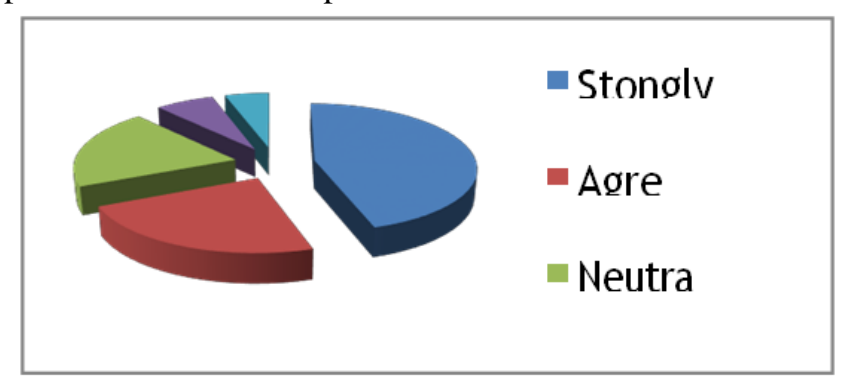

Fig. 1 - Users Feedback toimprove product and services

\section{B. CRM used in measuring and monitoring customer satisfaction levels.}

According to the response from the participants it was about $68 \%$ of the respondents totally frequently used and greatly used recommended the CRM used in measuring and monitoring customer satisfaction levels. Very least amount $0.08 \%, 0.06 \%$ of the respondents said it's not at all used to monitor the satisfaction level respectively shown in Fig. 2

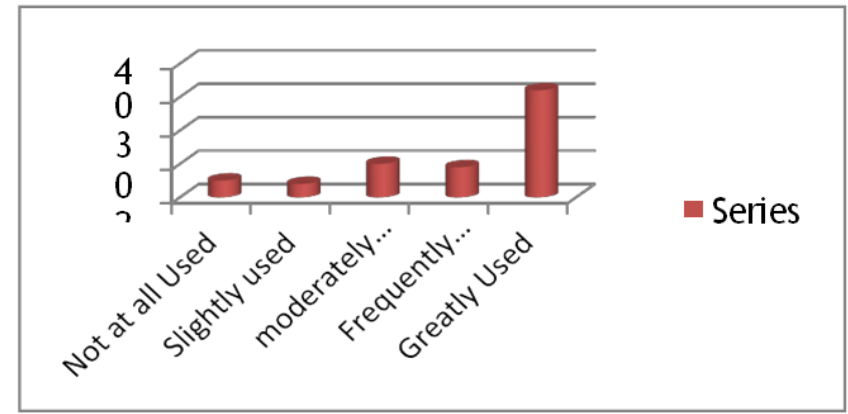

Fig. 2 - CRM used in measuring Customer satisfaction level

C. CRM used in measures and monitors customer defection and retention levels

Fig. 3 indicates that $30 \%$ of the respondents agree and $26 \%$ strongly agree that the CRM increases the customer retention levels in their organization and $12 \%$ are neutral and $08 \%$ and $06 \%$ of the respondents dis agree and strongly disagree respectively that CRM didn't measure any customer retention activity in their organization.

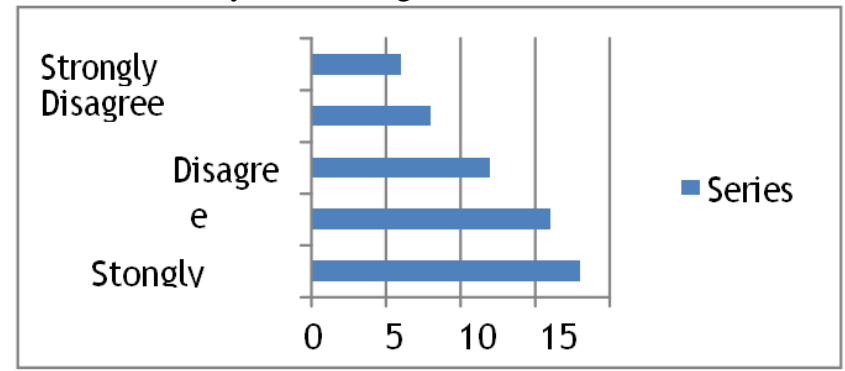

Fig. 3 - CRM used in measuring customer retention

\section{D.CRM helps in retaining profitable customers and produce new customers}

According to Fig. 4 partial amount of the respondents believe that CRM plays an important role in retaining profitable customers (43\%) as well as it also helps in understanding customer behaviour $(38 \%)$ by the way of satisfied guests and the other half of the represents $31 \%$ and $40 \%$ respectively says that it's not helps in understand guest behaviour . 25\% and $21 \%$ are neutral in retaining profitable customer and understanding behaviour respectively

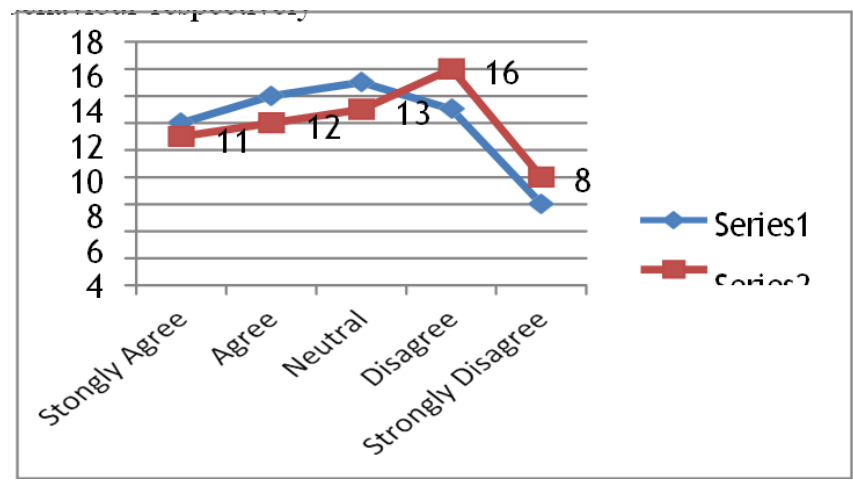

Fig. 4 - Retain profitable Customers and guest behaviour 


\section{SECTION - II - GUEST PERFORMANCE}

\section{A. CRM helps to increase percentage of reputed guests} and new guests

As shown in Fig. $561 \%$ and 54\% of the participants agree and strongly agree respectively that CRM helps to meet the guest expectation by means of guest retention and acquiring new guests by the way of guest satisfaction. And at the least amount of (10\% and $14 \%)$ only disagree strongly disagree that CRM didn't meet the guest expectations which means it's not helps in retaining the guests.

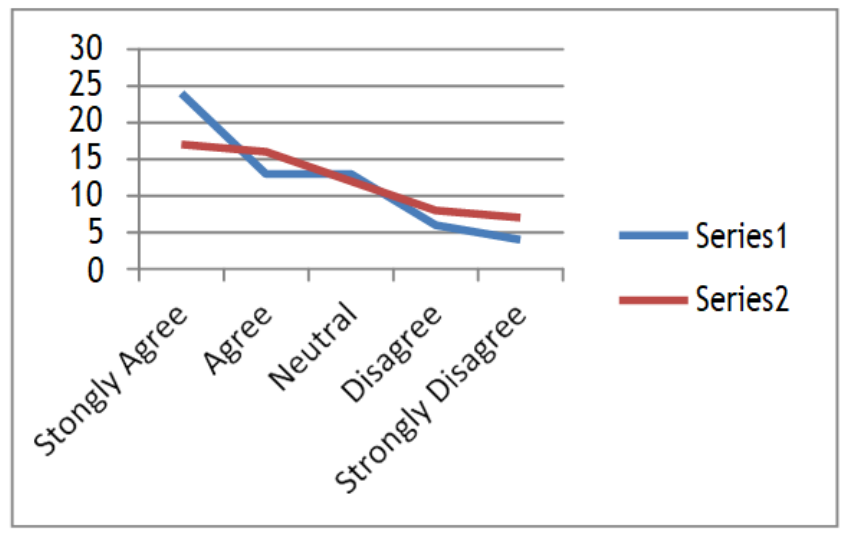

Fig. 5 - Increase Percentage of reputed guests and new guests

B.CRM influences in customer Profitability

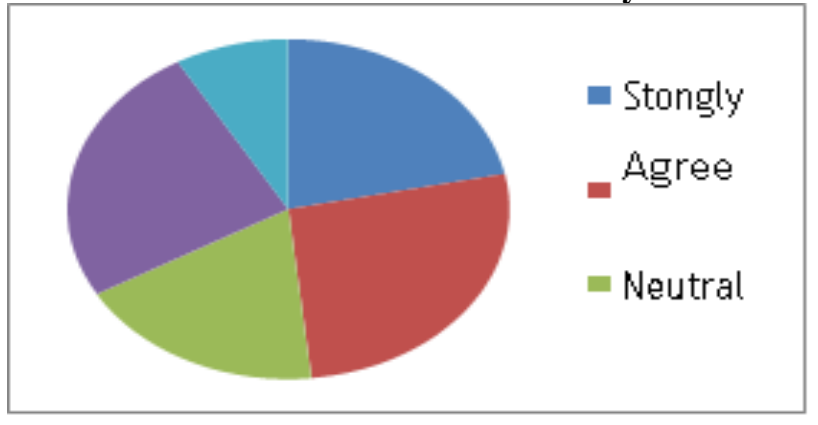

Fig. 6 Represents the customer profitability by the way of CRM almost $48 \%$ of the represents Strongly agree and agree that it will help and 18\% are neutral and $33 \%$ of the respondents disagree that it will not help in customer profitability.

\section{CONCLUSION}

After the careful analysis of the results which got during the survey it has been observed that the survey area has an adequate awareness about the importance of customer relationship in addition the respondents reveal that the CRM emphatically supportive to develop their products, holding their existing customers and acquiring new customers. This survey study concludes that there is a significant connection between the CRM Strategy and organizational achievement. It is noteworthy that deliberate planning and execution of CRM in their organization it will lead to retain and improve the market share. Top management and middle management should endeavour to reinforce CRM activity in the organization in order of priority to achieve more among the competition. This implies inns ought to have a solid client centre staffs; responsive hierarchical structure with authoritative generosity and muscle to execute CRM rehearses since the accomplishment of the firm lays on it.

\section{REFERENCES}

1. A. A. B. Balaram, "Managing Customer Relationships in Service Organizations," Administration and Management Review, vol. 21, no. 2, pp. 65-78, 2010.W.-K. Chen, Linear Networks and Systems (Book style). Belmont, CA: Wadsworth, 1993, pp. 123-135.

2. S. I. R. Ozgener, "Customer Relationship Management in Small - medium enterprises: The Case of Turkish tourism industry," Tourism Management, vol. 27, no. 6, pp. 1356-1363, 2006.B. Smith, "An approach to graphs of linear forms (Unpublished work style)," unpublished.

3. G. Dowling, "Customer Relationship Management: In B2C Markets, Often Less is More.," California Management Review, vol. 44, no. 3, pp. 87-104, 2002.

4. J. Wang, "Fundamentals of erbium-doped fiber amplifiers arrays (Periodical style-Submitted for publication)," IEEE J. Quantum Electron., submitted for publication.

5. R. Stockdale, "Managing Customer Relationship in the self service environment of e-tourism.," Journal of vacation Marketing, vol. 13, no. 3, pp. $205-219,2007$.

6. S. C. R. Verma, "Effect of CRM on Customer Satisfaction in Service Sector in India." Journal of Marketing and Communication, vol. 5, no. 2, pp. 5269, 2009.

7. N. D. E. G. S. A.-L. N. Akroush, "Customer Relationship Management implementation. An Investigation of a scale's generalizability and its relationship with business performance in a developing country context.,' International Journal of Commerce and Management, vol. 21, no. 2, pp. 158-191, 2011.

8. A. M. S. Y. R. Abdullateef, "The impact of CRM Dimensions on Call center Performance.," International Journal of Computer Science and Network Security, vol. 10, no. 12, pp. 184 - 195, 2010.

9. A. B. D. a. J. W. Zablah, "An Evaluation of Divergent perspectives on customer relationship: Towards a common understanding of an emerging phenomenon.” Industrial marketing Management, vol. 33, p. 475, 2004.

10. G. o. P. C. C. A. Piccoli, "Customer Relationship Management: A Driver for change in the structure of the U.S Lodging industry.," in Cornell Hotel and Restaurant Administration, U.S, 2003.

11. K. a. J. E. Richards, "Customer relationship management: Finding Value drivers.” Industrial Marketing Management, vol. 37, no. 2, pp. 120-130 2008.

12. M. Sigala, "integrating Customer relationship Management in hotel operations: Managerial and operational implications." International Journal of Hospitality Management, vol. 24, no. 3, pp. 391-413, 2005.

13. R. a. N. D. Kaplan, "Using the Balanced scorecard as a strategic management system," Harvard Business Review, pp. 75-85, January February 1996.

14. B. K. S. a. R. L. Noone, "Integrating customer relationship management and revenue management: A hotel Perspective.," Journal of Revenue and Pricing Management, vol. 2, no. 1, pp. 7-21, 2003.

15. R. Bose, "Customer relationship Management: key components for IT Success.," Industrial Management and Dot Systems, vol. 102, no. 2, pp. 89-97, 2002.

16. C. Gronroos, "The Relationship Marketing Process: Communication, Interaction, dialogue, value." Journal of Business and Industrial Marketing. vol. 29, no. 2, pp. 99-113, 2004.

17. P. Kotler, "When to use CRM and When to forgot it!.," in Academy of Marketing Science, Sanibel harbor Resort and Spa, 2002.

18. Y. S. H. Lin, "Strategic analysis of Customer Relationship Management - a field study on hotel enterprises.," Total Quality Management, vol. 56, no. 6, pp. 715-731, 2003.

19. C. O. M. Dev, "Marketing challenges for the next decade.," Cornell Hotel and Restaurant Administration, pp. 41-47, Quarterly 2000.

20. P. A. G. P. N. Papastathopoulou, "Intra organizational information and communication technology diffusion: implication for industrial sellers and buyers.," International marketing Management, vol. 36, no. 3, pp 322-336, 2007.

21. M. C. D. Singala, "In search of the next big thing: IT issues and trends facing the hospitality industry - A review of the Sixth Annual pan European Hospitality Technology Exhibition and Conference," Tourism Management, vol. 25, no. 6, pp. 807-809, 2004.

22. S. L. P. Wu, "The Relationship between CRM, RQ and CLV based on different hotel preferences.," International Journal of Hospitality Management, vol. 30, pp. 262-271, 2011 
23. S. a. G. M. Brown, Performance Driven CRM: How to make your customer relationship management visions a reality., Ontario: John Wiley, 2002.

24. A. C. W. D. B. Beldi, "Managing Customer Relationship Management Projects: The case of a large French telecommunications company.," International Journal of Project Management, vol. 28, no. 4, pp.339-351, 2010

25. L. S. C. H. C. Bunthuwun, "Effective Customer Relationship management of health care: A study of the perception of service quality, cooperate image, satisfaction and loyalty of that outpatients of private hospital iin Thailand.," in ASBBS Annual Conference, Las Vegas, 2011.

26. D. S. M. Luck, "An Evaluation of the Significant Elements of Customer Relationship Management with the Hotel Industry," Tourism Today, vol. 9, pp. 7-26, 2009.

27. L. C. Wu. S., "The Relationship between CRM, and business performance: A study of the hotel industry in Taiwan," International Journal of Hospitality Management, Vol. 18, no.7, pp. 276 - 285, 2012

\section{AUTHORS PROFILE}

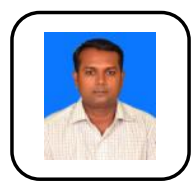

Mr. S.Senthilkumar, completed DHMCT at SIHMCT,Thuvakkudi and Post Graduation M.Sc; Hotel Management at Madurai Kamaraj University. Currently working as an Assistant Professor, Department of Catering Science \& Hotel Management, Kalasalingam University, Krishnan koil, Tamilnadu. jlpnos@gmail.com.

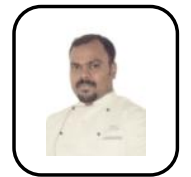

Mr. J.Prabhu, Completed B.Sc; in Hotel management in Sri Kaliswari College, Sivakasi. Completed M.B.A; in Tamilnadu Open University, Chennai. He poses 4 years industry experience and 9 years in Teaching Experience. Currently working as an Assistant Professor, Department of Catering Science \& Hotel Management, Kalasalingam University, Krishnan koil, Tamilnadu.Prabhu.j@klu.ac.in 